\title{
Pengaruh Kesenian Jathilan dan Joged Bumbung bagi Kehidupan Sosial Budaya Masyarakat: Studi Kasus pada Etnis Jawa dan Bali di Lampung, Indonesia
}

\author{
I Wayan Mustika ${ }^{1^{*}}$, Putu Setyarini ${ }^{2}$ \\ ${ }^{1}$ Jurusan Pendidikan Bahasa dan Seni, FKIP, Universitas Lampung, Indonesia, \\ ${ }^{2}$ Jurusan Sisitem Informasi, Fakultas Infokom, ITB STIKOM Bali, Indonesia \\ wayanmustika75@yahoo.com ${ }^{1 *}$,putusetyarini57@gmail.com ${ }^{2}$
}

\begin{abstract}
Masyarakat Lampung asal suku Bali dan Jawa yang mendiami Daerah Seputih Banyak Kabupaten Lampung Tengah memiliki kesenian jathilan dan joged bumbung sebagai bagian kesenian daerah asalnya. Kedua kesenian ini menjadi kebanggaan dan dapat menjalin hubungan yang erat dalam kehidupan bermasyarakat. Untuk melihat pengaruh yang ada dalam kesenian jathilan dan joged bumbung ini digunakan pendekatan etnokoreolgi dan sistem kemasyarakatan. Etnokoreologi dipandang mampu melihat, menelaah, dan menjawab berbagai bentuk tariantarian daerah dari berbagai suku. Metode lapangan dan kepustakaan digunakan untuk mengkaji dan menelaah pengaruh dari kedua kesenian ini dalam hubungan bermasyarakat. Untuk itu, kehidupan masyarakat dari kedua suku ini sangat toleran dari sisi seni, sosial, dan budaya. Tidak mengherankan bahwa, hubungan sosial yang baik ini sampai terdapat dua kesenian rakyat dari jenis, asal usul, dan budaya yang berbeda dapat dijadikan perekat dalam hubungan sosialnya. Kerapkali dalam upacara keagamaan, perkawinan, maupun hari besar nasional kesenian ini sering tampil. Dalam penampilan kesenian tersebut selalu ramai dikunjungi oleh kedua etnis ini, baik dari kalangan anak-anak, remaja, dan orang tua. Pertunjukan jathilan dan joged bumbung sama-sama dalam pementasannya berbentuk arena. Penari dikelilingi penonton yang secara bebas melihat dari mana saja. Kesenian jathilan secara umum ditampilkan pada siang sampai sore hari, sedangkan joged bumbung dipentaskan pada malam hari.
\end{abstract}

Kata kunci : Ethnocoreology, jathilan, joged bumbung, etnis, Bali, Jawa, pertunjukan seni

\section{The Influence of Jathilan and Joged Roofing Arts for The Socio-Cultural Life of The Community: Case Studies on Javanese and Balinese Ethnicity in Lampung, Indonesia}

The people of Lampung from the Balinese and Javanese tribes who inhabit the Seputih Banyak area of Central Lampung Regency have the arts of jathilan and joged bubung as part of their native arts. Both of these arts become the pride and can establish a close relationship in social life. To see the influence that exists in the arts of jathilan and joged bumbung, an ethnocoreological approach and a social system are used. Ethnochoreology is seen as capable of seeing, studying, and responding to various forms of regional dances from various tribes. Field and library methods are used to examine and examine the influence of these two arts in social relations. For this reason, the lives of the people of these two tribes are very tolerant in terms of art, social and culture. It is not surprising that this good social relationship until there are two folk arts of different types, origins, and cultures can be used as glue in social relations. Often in religious ceremonies, weddings, and national holidays this art appears. In the art performances, these two ethnic groups are always visited by both children, teenagers, and the elderly. Both jathilan and joged bubung performances are in the form of an arena. The dancers are surrounded by spectators who can freely watch from anywhere. Jathilan art is generally performed in the afternoon until the evening, while joged bumbung is performed at night.

Keywords: Ethnocoreology, jathilan, joged bumbung, ethnicity, Balinese, Javanese, performing arts

Received: October 12, 2021; Accepted February 7, 2022; Published February 8, 2022 https://doi.org/10.31091/mudra.v37i1.1896

(C) 2021 The Author(s). Published by Pusat Penerbitan LP2MPP Institut Seni Indonesia Denpasar. This is an open-access article under the CC BY-NC-SA license 


\section{PENDAHULUAN}

Lampung merupakan salah satu provinsi di Indonesia yang multietnik dan multibahasa. Di Kabupaten Lampung Tengah, misalnya, kabupaten ini terdiri dari berbagai etnik, di antaranya, Lampung, Jawa, Sunda, Bali, dan lain sebagainya. Beragamnya etnik tersebut tidak lepas dari peran pemerintah dalam rangka pemerataan pembangunan demi tercapainya asimilasi dan integrasi bangsa. Selanjutnya, areal transmigrasi tersebut diserahkan kembali pada pemerintah daerah bersangkutan untuk dilakukan pembinaan dan pengembangannya (Pemda Lamteng: 2006). Hasilnya, seiring peningkatan, penyebaran dan pemerataan penduduk, terbentuklah keanekaragaman suku bangsa di Provinsi Lampung, termasuk di Kabupaten Lampung Tengah. Sementara transmigran yang berasal dari luar Pulau Jawa mayoritas adalah etnis Bali yang mendiami beberapa kecamatan di wilayah Seputih Banyak. Dengan adanya bermacam suku bangsa ini tentu saja kehidupan sosial budaya di Kabupaten Lampung Tengah relatif beragam. Setiap suku bangsa selalu membawa unsur-unsur kebudayaannya (Koenjtaraningrat: 1990: 89), sehingga membentuk semacam Indonesia mini. Hal yang mencolok dari keragaman tadi, selain bahasa, juga pada kesenian tradisional yang kerap ditampilkan pada acara-acara tertentu (perkawinan, sunatan, dan upacara daur hidup lainnya).

Kecamatan Seputih Banyak Lampung Tengah terdapat penduduk terbesar dari dua etnis yang berbeda yaitu etnis Jawa dan Bali. Kehidupan masyarakanya sangat harmonis dilihat dari sudut agama, seni, sosial, dan budaya. Sebuah pemandangan yang sangat indah, dimana keunikan dari kedua etnis tersebut sangat nampak yaitu ketika ada sebuah pertunjukan atau hiburan kesenian tradisional. Misalnya kesenian jathilan dan joged bumbung yang selama ini mampu menghadirkan semua kalangan dan dapat memikat dari kedua etnis tersebut untuk bersama-sama menikmati dari kedua unsur kesenian itu. Ditinjau dari bentuk penampilannya, kedua kesenian tersebut memiliki unsur kesamaan yaitu, unsur pementasannya melingkar atau arena, sebagai hiburan bagi kalangan masyarakat biasa, dan juga bisa disaksikan semua kalangan.

Untuk mendapatkan kajian dari bentuk kedua jenis kesenian dan hubungan sosial yang sangat baik dari kedua etnis tersebut, perlu dilakukan penelusuran melalui sebuah penelitain, agar mendapatkan kajian yang sangat mendalam sebagai contoh atau model untuk kehidupan sosial pada masyarakat lainnya.
Dari paparan di atas, dapat dirumuskan permasalahan dan paradigma dari kedua bentuk kesenian dan hubungan sosial ini yaitu pengaruh kesenian jathilan dan jogged bumbung bagi kehidupan sosial budaya masyarakat di Lampung tengah khususnya Kecamatan Seputih Banyak. Untuk melihat pengaruh kesenian jathilan dan joged bumbung bagi kehidupan sosial budaya pada masyarakat etnis Jawa dan Bali, serta melihat bentuk pertunjukan kesenian tersebut di kalangan masyarakat transmigran etnis Jawa dan Bali yang berada di Kecamatan Seputih Banyak Kabupaten Lampung Tengah.

Kehidupan seni pertunjukan pada dasarnya merupakan bagian dari perjalanan suatu budaya yang sangat ditentukan oleh masyarakat pendukungnya, yang dalam prosesnya mengalami perkembangan. Di samping itu, masalah-masalah sosial yang terjadi di masyarakat dengan melibatkan seni pertunjukan kerapkali terjadi. Seni pertunjukan memiliki hubungan yang sangat erat dengan kehidupan masyarakat dan lingkungannya. Seni bukan saja berkaitan dengan ekonomi, sosial, budaya tetapi lebih dari itu, serta seni dikatakan sebagai produk masyarakat. Produksi 'hasil' karya seni tergantung pada proses sociohistorical pada sejumlah faktor yang beragam (Hauser, 2005: 94). Untuk mengamati perkembangan seni pertunjukan Indonesia dari masa lampau sampai ke era globalisasi, diperlukan penelusuran sejarah maupun asal usul jejak sebuah kesenian (Soedarsono, 2002: 61). Kesenian etnik ini dapat ditelusuri dengan dipayungi etnokoreologi yang dapat mengungkap tentang seni pertunjukan (Narawati, 2003). Di samping itu, seni pertunjukan juga sangat multi lapis yang terdiri dari gerak, penari, rias, busana, iringan, tempat pertunjukan, dan juga tata lampu (Marinis, 1993: 10). Kajian pertunjukan berangkat dari dasar pemikiran bahwa, pertunjukan tidak dibatasi oleh bentuk pertunjukan tradisional, tetapi dijabarkan kepertunjukan yang lebih luas (Schechner, 2002). Kemudian, aspek yang digunakan dalam sebuah seni pertunjukan adalah bentuk atau jenis dari sebuah kesenian dan fungsi seni pertunjukan tersebut (Mustika, 2012:30). Begitu pula bahwa, fungsi seni pertunjukan ada beberapa yaitu sebagai ritual, hiburan, tontonan, dan juga sebagai penyajian estetis (Soedarsono, 2002: 170). Begitu juga untuk melihat pengaruh kesenian jathilan dan joged bumbung digunan teori fungsi. Oleh karena itu, kedua bentuk kesenian jathilan dan joged bumbung di Kecamatan Seputih Banyak Lampung Tengah dapat dilihat dari berbagai bentuk penampilannya dan hubungan sosial masyarakat dari kedua etnik tersebut 
Kecamatan Seputih Banyak terdapat 13 desa yang sebagian besar masyarakatnya dari etnis Jawa dan Bali. Kedua etnis ini merupakan masyarakat transmigrasi pada tahun 1957 datang dari pulau Jawa dan Bali menuju ke Lampung khususnya Lampung Tengah. Kehadiran kedua etnis ini di Seputih Banyak tidak saja sebagai petani dan peternak. Akan tetapi, semua tata cara dan kebiasaan adat istiadat yang ada di daerah asalnya juga dibawa sebagai dari bagian identitas asal-usul. Misalnya adat perkawinan, bahasa, nama desa asal, dan juga bentuk olahan makanan. Salah satu keunikan yang dimiliki oleh desa ini dengan keaneka ragam bentuk kesenian. Kesenian yang berkembang sebagian besar adalah seni wayang, jathilan, dan juga seni campur sari. Bagi masyarakat etnis Bali yang sering ditampilkan adalah tari joged bumbung. Kesenian jathilan bermula dan berkembang di Desa Setia Bakti atau disebut dengan SB 14 yang sampai saat ini masih dipimpin oleh Bapak Sutomo. Lebih lanjut diceritakan bahwa:

\begin{abstract}
"Kesenian Jathilan sangat digemari oleh kalangan anak kecil dan juga anak muda yang berada di Desa SB 14 ini. Mereka adalah semula kumpulan pemain seni jaranan yang selama ini telah terbina. Kemudian, mereka dipilih berdasarkan umur untuk menentukan posisi atau peranannya"
\end{abstract}

Desa Setia Bakti adalah salah satu desa yang terdapat tiga kelompok kesenian jathilan yang sebagian besar dari etnik Jawa. Ketiga kelompok ini saling bergantian melakukan pementasan dan pemainnya pun bisa saling tukar kelompok. Hal ini memberikan nuansa atau warna lain dalam pengkemasan seni jahilan. Di samping itu, rasa kebersamaan dan keakraban sangat terjalin sesama kelompok jathilan di Desa SB 14.

\section{METODE PENELITIAN}

Penelitain ini merupakan penelitian deskriftif kualitiatif yang kerap dugunakan menganalisis fenomena, peristiwa, aktivitas sosial, sikap, kepercayaan, persepsi, pemikiran orang secara individu maupun kelopompok (Ardiano dan Bedjo Riyanto, 2020: 113). Penelitian pengaruh kesenian jathilan dan joged bumbung bagi kehidupan sosial budaya pada masyarakat suku Jawa dan Bali digunakan metode lapangan dan kepustakaan yang meliputi, observasi, wawancara, dokumentasi, dan referensi berupa buku, majalah, catatan, atau sumber langsung dari kedua masyarakat yang berbeda etnis tersebut. Dengan digunakan metode tersebut tentu akan lebih banyak bisa berkreasi dalam menelusuri data-data dari kedua jenis bentuk pertunjukan itu, serta data yang didapatkan secara langsung ke narasumber yang masih hidup. Berkaitan dengan jenis penelitian ini, maka data penelitian dikumpulkan dengan metode dokumentasi dengan teknik catat (Karmini, 2019:10). Kemudian, dibantu pula dengan model pengembangan (research and development) yang bertujuan untuk menghasilkan produk baru melalui proses pengembangan dari kedua bentuk seni pertunjukan ini yaitu jathilan dan joged bumbung.

\section{ANALISIS DAN INTEPRETASI DATA}

Penelitian ini bertujuan untuk menganalisis dan pentingnya eksistensi dari pengaruh kesenian jathilan dan joged bumbung yang erat kaitannya dengan kedua budaya yang berbeda dalam satu wilayah di daerah transmigrasi Seputih Banyak Kabupaten Lampung Tengah. Dengan data lapangan dan kepustakaan dapat menghadirkan informasi dan dokumen yang sahih terhadap seni pertunjukan jathilan dan joged bumbung. Dengan begitu, hasil dari kajian ini dapat menghadirkan perubahan sosial dimana seni pertunjukan dapat memberikan kehidupan yang harnonis dari masyarakat yang berbeda agama, suku, bahasa, adat, dan kesenian. Begitu pula dapat menghadirkan sikap, perilaku yang berkarkarakter, dan bijaksana dalam menjalin hubungan baik dalam bermasyarakat (Handayani dan Sunarso, 2020:235). Disamping itu, kajian tentang bentuk seni pertunjukan ini dapat terungkap di daerah transmigrasi. Capaian yang terbesar dapat diraih yaitu mampu mempertahankan seni pertunjukan tradisional atau kesenian rakyat untuk bangsa Indonesia yang dalam hal ini terkena dampak arus globalisasi. Diskusi dengan nara sumber, pengambilan gambar, peliputan, dan juga pemilahan atau seleksi data sumber dari seni pertunjukan jathilan dan joged bumbung dengan para tokoh seniman atau ketua penguyuban kedua kesenian tersebut. Kehadiran kedua masyarakat etnis yang berbada menjadikan dasar untuk mendapatkan pengaruh dari kedua bentuk kesenian itu. Toleransi dan kerukunan menjadi sumber utama dalam kaitannya. Dengan demikian hasil ini bisa disebarluaskan ke masyarakat lainnya bahwa, seni pertunjukan dapat menghadirkan sebuah kerukunan dalam kehidupan yang komunitasnya berbeda agama, suku, adat, dan juga bentuk kesenian.

\section{Pendekatan dan Partisipan}

Istilah etnokoreologi (ethnochoreology) sebagai pengganti istilah yang di Barat lazim disebut sebagai etnologi tari (dance ethnology) atau antropologi tari 
(dance anthropology) mulai diperkenalkan $\mathrm{di}$ Indonesia sejak akhir abad ke-20. Istilah ini ternyata lebih tepat digunakan karena dalam pelaksanaan penelitiannya lebih bisa mencakup aspek-aspek tekstual dan kontekstual dengan pendekatan multidisiplin. Makalah ini mencoba mengaplikasikan teori etnokoreologi dengan mengurai praktis mengamati seni tari untuk selanjutnya diakomodasikan dalam praktis menyaji (Tati Narawati, 2013). Etnokoreologi sebagai payung untuk mengupas seni tari yang ada di wilayah dan suku dari kehidupan manusia di dunia ini. Kemudian, dibantu pula dengan model pengembangan (research and development) yang bertujuan untuk menghasilkan produk baru melalui proses pengembangan dari kedua bentuk seni pertunjukan ini yaitu jathilan dan joged bumbung. Alur dalam metode lapangan dan kepustakaan yang meliputi, observasi, wawancara, dokumentasi, dan referensi berupa buku, majalah, catatan, atau sumber langsung dari kedua masyarakat yang berbeda etnis. Dengan digunakan metode tersebut tentu akan lebih banyak bisa berkreasi dalam menelusuri data-data dari kedua jenis bentuk pertunjukan itu, serta data yang didapatkan secara langsung ke narasumber yang masih hidup.

\section{Bentuk Pertunjukan Kesenian Jathilan}

Seni pertunjukan tradisional tercipta sebagai suatu peninggalan yang mempunyai nilai-nilai luhur dan kecenderungan bersifat religius, sehingga para pelaku seni dan masyarakat yang memilikinya merasa bangga. Seolah-olah seni pertunjukan tradisional tersebut sebagai wadah dari penuangan hasrat naluri kejiwaannya. Hal tersebut sesuai dengan pendapat Hauser bahwa, seni tidak dapat dilihat sebagai sebuah bahasa asli melainkan sebagai sebuah bahasa universal yang dapat dipahami oleh semua orang dan sepanjang waktu dan merupakan alat ekspresi (Hauser, 1982: 29). Begitu juga terjadi dalam kehidupan tradisional yang menjadikan seni tari merupakan seni tradisional. Terlihat dari cara pengemasan kesenian kadang kala dibuat sesuai dengan selera pelaku atau penggarapnya, di samping disesuaikan pula dengan kebutuhan kehidupan sosialnya. Jathilan adalah sebuah kesenian yang menyatukan antara unsur gerakan tari dengan magis. Jenis kesenian ini dimainkan dengan properti berupa kuda tiruan, yang terbuat dari anyaman bambu atau kepang. Kesenian yang juga sering disebut dengan nama jaran kepang ini dapat dijumpai di daerahdaerah Jawa. Kesenian Jathilan ini menggambarkan tentang ketangkasan prajurit berkuda yang sedang berlatih. Ketangkasan dan kepiawaian dalam berperang dituangkan kedalan ekspresi dan semangat para penarinya.
Kesenian jathilan berkembang di daerah Lampung terutama di Kecamatan Seputih Banyak Kabupaten Lampung Tengah. Kesenian ini dibawa oleh masyarakat Jawa yang transmigran ke Lampung. Kesenian ini pun hidup dan berkembang di Lampung. Kesenian jathilan disukai banyak masyarakat dengan berbagai lapisan, hal ini dikarenakan oleh bentuk tampilannya yang menarik. Pertunjukan kesenian ini biasa dilakukan dilapangan yang mana merupakan tempat bertemu masyarakat. Penonton dari kesenian jathilan sangat heterogen, mulai dari anak-anak, remaja, orang dewasa, serta dari berbagai etnik, sehingga dapat menghadirkan segala lapisan masyarakat. Terdapat beberapa sanggar kesenian jathilan yang sampai saat ini masih berkembang dan terus melestarikan kesenian ini di Kecamatan Seputih Banyak. Sanggar-sanggar jathilan tersebut hidup dan berkembang sesuai dengan perkembang zaman. Peserta dari sanggar tersebutpun tidak hanya diminati oleh masyarakat Seputih Banyak, melainkan dari kecamatan lain juga.

Pagelaran kesenian ini dimulai dengan tari-tarian oleh para penari yang gerakannya sangat pelan tetapi kemudian gerakanya perlahan-lahan menjadi sangat dinamis mengikuti suara gamelan yang dimainkan. Gamelan untuk mengiringi jathilan ini cukup sederhana, hanya terdiri dari drum, kendang, kenong, gong, dan slompret, yaitu seruling dengan bunyi melengking. Lagu-lagu yang dibawakan dalam mengiringi tarian, biasanya berisikan himbauan agar manusia senantiasa melakukan perbuatan baik dan selalu ingat pada Sang Pencipta, namun ada juga yang menyanyikan lagu-lagu lain. Setelah sekian lama, para penari kerasukan roh halus sehingga hampir tidak sadar dengan apa yang mereka lakukan, mereka melakukan gerakangerakan yang sangat dinamis mengikuti rancaknya suara gamelan yang dimainkan. Para penari dan para pemain gamelan, dalam pagelaran jathilan pasti ada pawang roh yaitu orang yang bisa "mengendalikan" roh-roh halus yang merasuki para penari. Pawang dalam setiap pertunjukan jathilan ini adalah orang yang paling penting karena berperan sebagai pengendali sekaligus pengatur lancarnya pertunjukan dan menjamin keselamatan para pemainnya. Tugas lain dari pawang adalah menyadarkan atau mengeluarkan roh halus yang merasuki penari jika dirasa sudah cukup lama atau roh yang merasukinya telah menjadi sulit untuk dikendalikan. Selain melakukan gerakan-gerakan yang sangat dinamis mengikuti suara gamelan pengiring, para penari itu juga melakukan atraksiatraksi berbahaya yang tidak dapat dinalar oleh akal sehat. Di antaranya adalah mereka dapat dengan 
mudah memakan benda-benda tajam seperti silet, pecahan kaca, menyayat lengan dengan golok bahkan lampu tanpa terluka atau merasakan sakit. Atraksi ini dipercaya merefleksikan kekuatan supranatural yang pada jaman dahulu berkembang di lingkungan kerajaan Jawa, dan merupakan aspek nonmiliter yang dipergunakan untuk melawan pasukan Belanda. Selain mengandung unsur hiburan dan religi, kesenian tradisional jathilan ini seringkali juga mengandung unsur ritual karena sebelum pagelaran dimulai, biasanya seorang pawang atau dukun melakukan suatu ritual yang intinya memohon ijin pada yang menguasai tempat tersebut yang biasanya ditempat terbuka supaya tidak menggangu jalannya pagelaran dan demi keselamatan para penarinya.

Penampilan kesenian jathilan di Desa SB 14 ceritanya tidak utuh sepeti di Jawa. Ada sebagian yang dihilangkan karena tidak terdapat pemain, tidak tersedianya busana, dan juga tidak dianggap menarik. Hanya sebagian cerita jathilan diambil yang dipandang mampu dapat menarik perhatian penonton. Misalnya seperti adegan-adegan yang ada gerak tari dan kesurupannya. Pada gerak tari kuda kepang yang sebagian besar pemainnya perempuan memang dirias cantik, agar menarik penonton. Tidak saja pada busana, tetapi goyangan pinggul dan penampilan sedikit seksi juga menjadi perhatian bagi penari kudang kepang. Kedinamisan gerak tari dengan kelincahan menjadi prioritas utama dalam konsep kuda kepang. Oleh karena itu, para penari sudah mempersiapkan hal tersebut sejak latihan. Kekompakan dalam menari kuda kepang adalah bagain yang paling disenangi baik bagi penari dan penonton. Kerapian dalam mengolah pola lantai dan penguasaan area pertunjukan jathilan wajib bagi penari kuda kepang memenuhinya. Dengan begitu akan terlihat rapi dan penuh area atau tempat pertunjukan jathilan. Hal lainnya yang menjadi pertimbangan bagi penari kuda kepang adalah kesamaan seragam busananya, karena busana bagian penting bagi penari yang semuanya perempuan untuk mewujudkan unsur keindahan. Semua pemain jathilan di kelompok paguyuban SB 14 menganggap kesenian jtahilan ada perpaduan atau gabungan bentuk penampilannya yaitu ada pemain perempuan dan ada pemain laki-laki dalam satu perjunjukan dengan konsep yang berbeda. Penari perempuan yang peranannya menunggang kuda-kudaan, sedangkan pemain laki-laki lebih menonjolkan kegagahan sebagai seorang pra sejati, serta memeintingkan aksi kesurupannya.

Adegan-adegan yang diluar batas kewajaran justru memberikan suasana dan nuasan yang sangat menarik bagi penonton. Adegan tersebut tentu ditunggu oleh penonton dengan rasa penasaran. Selama ini, itulah yang menjadi daya tarik kesenian jathilan yang ada di Desa SB 14 sebagai bagian dari ciri khas kesenian jathilan. Nilai yang ditawarkan dari kelompok jathilan ini dapat memberikan hiburan yang selama ini dapat menghadirkan banyak orang. Tidak saja dari satu kalangan suku, tetapi suku-suku lain pun ikut menonton dan hadir ditengah-tengah pementasan kesenian jathilan, misalnya suku Bali sebagai tetangga paling dekat. Keakraban suku Bali yang berada di Desa SB 15, 17, dan 16 sangat mempengaruhi situasi dan perkembangan budaya bagi desa SB 14 yang sebagian besar suku Jawa. Keterliban ini terlihat anak-anak dari suku Bali di Seputih Banyak ada juga ikut belajar kesenian jathilan, terutama pada bagian gerakan yang ada atraksi. Mereka senang berbaur dalam satu bentuk kesenian yang menawarkan kebebasan menggunggapkan dan menuangkan eksperi. Puji Astuti salah satu penari senior kuda kepang mengatakan bahwa, sebagai penari kuda kepang dalam kesenian jathilan di Seputih Banyak adalah kebanggaan dan memiliki pengalaman yang peribadi. Pengalaman masa remaja sebagai penari kuda kepang tidak akan terulang kembali, karena sudah berkeluarga. Sekarang Puji Astuti sebagai pelatih penari kuda kepang bagi anak-anak gadis di Desa SB 14. Ia menularkan dan memberikan semua pengetahuan dan pengalamannya selama menjadi penari kuda kepang di masa lalu. Harapannya adalah, agar generasi sekarang tetap mencintai dan melestarikan kesenian jathilan ini sebagai warisan asal-usul suku Jawa yang ada di Lampung. Dengan adanya situasi wabah covid 19 ini, Astuti hanya bisa latihan di rumah dengan anak-anak yang sudah terdaftar dipaguyuban kesenian jatrilan. Menu latihan ini tetap dilakukan dengan terstrutur dari kap kepala, tangan, badan, dan kaki. Begitu juga iringannya menggunakan media handphone. Tujuan dari latihan ini ada dua yaitu, tetap mengolah tubuh, agar tetap lentur dan kedua yaitu menjaga kesehatan untuk menjaga kondisi tubuh tetap sehat (Wawancara: Mistam dan Sutomo, 23 Agustus 2020).

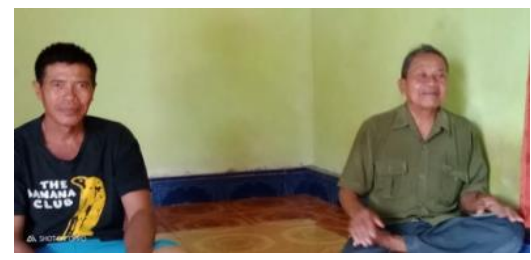

Gambar 1. Mistam dan Bapak Sutomo sebagai kesenian jathilan di Desa Setia Bakti SB 14 Kecamatan Seputih Banyak kabupaten Lampung Tengah (Sumber : Andreas, 2020) 
Untuk penari laki-laki latihan dilakukan di rumah ketua paguyuban jathilan. Mereka anak-anak muda dilatih berbagai atraksi dengan cara mengolah tubuhnya dengan geran-gerakan yang sangat rumit. Totalitas menuangkan ekspresinya dituntut oleh pelatih, agar lebih mudah menerima teknik gerak yang dipangdang sulit. Nilai yang ditawarkan dalam kesenian jathilan ini ada pada antraksi. Kemampuan olah tubuh mereka dijadikan media untuk daya tarik bagi penonton. Kelenturan dan kelihaian penari lakilaki dalam beratraksi sangat ditunggu bagi penonton. Oleh karena itu, dengan atraksi dan penari kuda kepang yang cantik dapat memiliki daya jual yang yang tinggi bagi penanggap. Dalam latihan ini semua peserta penari untuk mempersiapkan penampilannya selalu bugar sebagai bentuk persiapan penampial pada bualan desember nanti untuk menyambut tahun baru 2021. Mereka semua berharap wabah ini pada akhir tahun sudah selesai, sehingga bisa pentas kembali. Karena selama ini ada permintaan untuk pentas lagi, hanya saja tidak dapat ijin pentas dari kepolisian di Kecamatan Seputih Banyak. Padahal situasi new normal ini ada penanggap kesenian jathilan dalam rangka syukuran tiga bulannan anak. Selama tuga bulan terakhir ini ada beberapa oang melaksanakan hajatan perkawinan dan juga syukuran keselamatan anak. Dengan dilarangnya mengumpulkan banyak orang dan tidak diperbolehkan mengadakan keramian menjadi musibah bagi kelompok kesenian jathilan di Desa Setia Bakti. Kegelisan paguyuban kesenian jathilan ini berdampak besar terhadap perekonomian mereka. Nilai tambahan tidak ada dan hanya bertopang pada sektor pertanian dan menjadi buruh. Memang hampir sebagaian besar masyarakat Desa Setia Bakti mengalami hal yang serupa dan begitu juga dengan masyarakat lainnya. Astuni menerangkan perjalannannya sebagai penari kuda kepang serta mengunggapkan kondisi atau keadaan paguyuban seni jathilan di desanya. (Wawancara: Puji Astuti, 28 Agustus 2020).

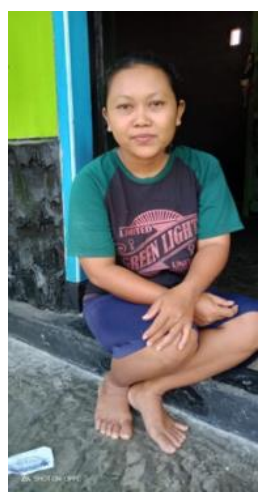

Gambar 2. Puji Astuti sebagai pelatih tari kuda kepang di Desa Setia Bakti SB 14, Kecamatan Seputih Banyak kabupaten Lampung Tengah (Sumber : Andreas, 2020).
Bentuk penampilan kesenian jathilan bagi penari laki-laki yang sebagian besar berorientasi pada atraksi dengan mengandalkan kelenturan tubuh dan keberanian dalam mengekplorasi gerak tentu dibutuhkan mental yang kuat. Penari laki-laki membutuhkan improvisasi yang banyak, agar mendapatkan model gerak yang berbeda dan itu bisa secara spontan. Kepiawian (expertise) adalah bakat dengan cara latihan secara terus menerus. Tidak banyak pemain jathilan mampu mengekspresikan model kesenian ini ke penonton. Dibutuhkan pergerakan total penuh dengan ekspresi yang timnul dari dalam penari (Wawancara: Sutomo, tgl 25 Agustus 2020).

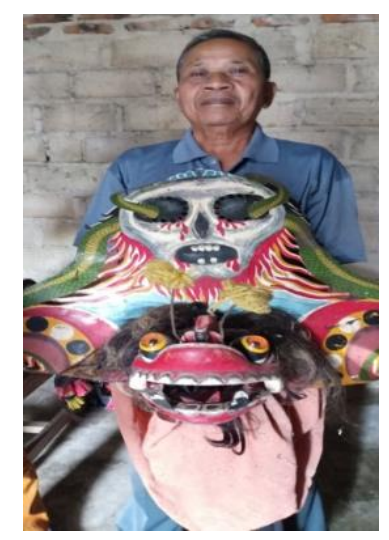

Gambar 3. Pak Sutomo memperagakan barongan di SB 14 Kecamatan Seputih Banyak

Kabupaten Lampung Tengah (Sumber : Mustika, 2020)

\section{Bentuk Pertunjukan Joged Bumbung}

Joged Bumbung merupakan sebuah kesenian masyarakat Bali yang sudah sangat terkenal, kesenian ini juga sudah diakui sebagai warisan budaya tak benda milik masyarakat Bali. Sama seperti jathilan kesenian joged bumbung juga berkembang tidak hanya di Bali melaikan kesenian ini ikut dengan masyarakat Bali yang bermigrasi ke daerah-daerah lain di seluruh Indonesia. Lampung merupakan salah satu provinsi di pulau sumatera yang memiliki banyak transmigran dari berbagai daerah di Indonesia. Bali salah satunya, masyarakat Bali menyebar diseluruh Kabupaten di Lampung salah satunya di Lampung Tengah dan kecamatan Seputih Banyak menjadi salah satu pusatnya. Masyarakat Bali yang bertransmigran juga membawa kebiasaan dan kebudayaannya, kesenian termasuk di dalamnya. Beberapa tarian dan musik tradisi Bali berkembang dan terus di lestarikan oleh masyarakat Seputih Banyak, salah satunya joged bumbung. Joged bumbung merupakan tari pergaulan yang sangat populer di Bali. Biasanya dipentaskan dalam acara-acara sosial kemasyarakatan di Bali, seperti acara pernikahan. Tarian ini ditarikan oleh 
penari wanita, yang kemudian mencari pasangan pria dari para penonton untuk diajak menari bersama. Tarian ini juga membutuhkan kelincahan gerak tubuh dan mata dari penarinya. Tarian ini diiringi dengan gamelan Tingklik bambu berlaras Slendro yang disebut Grantang atau Gamelan Gegrantangan.

Tarian ini awalnya adalah diciptakan untuk menghibur petani dikala sedang istirahat setelah bekerja. Tarian ini pun banyak diminati oleh masyarakat dan menjadi sebuah kelompokkelompok seni. Persaingan yang baik dan sehat mengakibatkan para kelompok-kelompok tari berinovasi dalam menciptakan gerak dan irama, sehingga tarian ini cepat berkembang sampai keluar daerah Bali. Tarian joged bumbung juga terdapat dan tersebar di beberapa kabupaten di Propinsi Lampung. seperti di Kabupaten Lampung Timur, Way Kanan, dan Kabupaten Lampung Tengah.

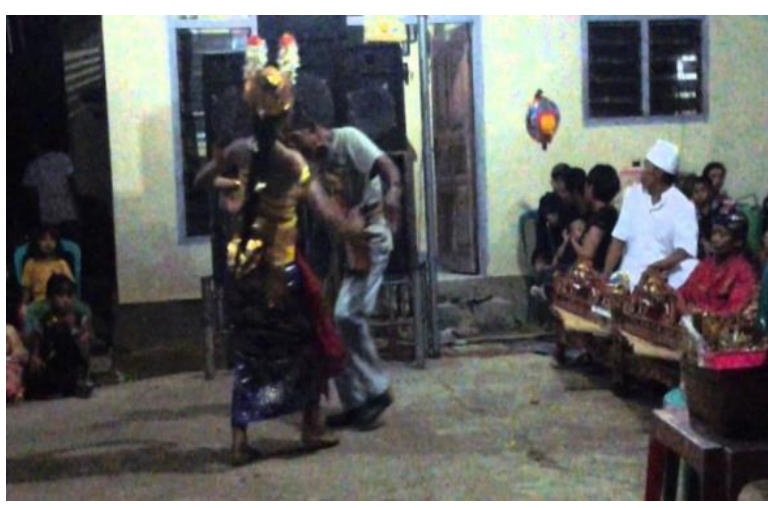

Gambar 3. Joged bumbung di Lampung Tengah dalam acara syukuran kelahiran seorang anak (Sumber : Pan Suratningsih, 2020)

Secara keseluruhan joged bumbung yang ada di kecamatan Seputih Banyak dengan yang ada di Bali serupa. Sama-sama digunakan untuk acara hiburan dan menjadi tradisi yang terus dijaga sebagai fasilitas berkumpulnya masyarakat. Namun ada sedikit perbedaan antara joged bumbung yang ada di Bali dengan di Lampung Tengah khususnya di Desa Joharan Kecamatan Putra Rumbia. Hasil wawancara dengan seniman joged bumbung di Seputih Banyak perbedaan paling menonjol adalah pada musik iringan. Di Bali musik iringan joged bumbung menggunakan iringan alat musik dari bambu dan lagu-lagu tradisi yang berkembang dimasyarakat Bali yang tentunya menggunakan bahasa Bali, sedangkan di Lampung sudah dikreasikan menggunakan orgen dan drum serta menggunakan lagu-lagu bergenre dangdut Indonesia.
Di Seputih Banyak Lampung Tengah joged bumbung biasa dipertunjukan dalam acara syukuran tiga bulanan anak-anak, acara pernikahan, acaraacara di pura serta acara hiburan lainnya. Masyarakat biasa menyebut rombongan atau kelompok joged bumbung di Seputih Banyak dengan sebutan SB 12 atau Seputih Banyak 12. Jumlah dari kelompok SB 12 ini kurang lebih 50 orang yang berisikan pemusik, penari, pendeta dan kru-kru lainnya. Sistem 'tanggap' berlaku untuk kelompok jogged bumbung ini. Masyarakat yang memiliki acara biasanya memanggil kelompok ini untuk menghibur dan pentas diacara mereka, hal ini menyebabkan SB 12 sangat laris dan menjadi kelompok idola Joged Bumbung di seputih banyak. Dalam kacamata gender di mana persoalan eksploitasi tubuh dan pelecehan terhadap harga diri wanita dianggap tabu. Pelecehan dan penistaan terjadi di sudut ruang pertunjukan. Pertama, eksploitasi wanita sebagai simbol penting dalam konsep seni pertunjukan seni joged Sinabun ditempatkan sebagai objek yang sangat mudah dipermainkan. Terjadinya penguasaan atas tubuh wanita dikatakan telah dipraktikan secara tidak sadar oleh wanita sendiri sebagai unsur pelaku (agency) dalam tindakan yang didominasi oleh kekuasaan. Agen-agen yang bermain di dalam seni joged bumbung meliputi pengontrak, pemimpin sekaa,(Wirawan, 2014;292-295).

Hal itu terjadi karena adanya ketidaksadaran atau kesadaran palsu yang muncul pada penari joged secara individual dan kelompok (pada masyarakat termasuk sekaa) yang bermain sebagai akibat dampak ekonomi yang bermain di dalamnya. Kenyataan yang terjadi konsep gender yang menempatkan wanita sebagai mahluk alamiah secara genetic memiliki naluri seks telah dimanfaatkan demi kepentingan kepuasan penikmat secara berlebihan telah dilakoni tanpa sadar. Ini adalah sebuah kenyataan di mana estetika dalam seni joged bumbung mengalami perubahan akibat tekanan ekonomi. Diterima atau tidak penurunan kadar estetika seni joged yang berkembang tidak lagi murni sebagai estetika untuk estetika. Kenyataan ini memberi petunjuk bahwa kesadaran rendah masyarakat di dalam menikmati bentuk keindahan perlu digaris bawahi. Seni joged bumbung memiliki dua versi, pertama adalah pertunjukan joged yang menekankan pada gaya atau ciri dari perpaduan antara keahlian menari duet (berdua), dengan fokus untuk saling menggoda satu sama lainnya lewat keahlian atau ketrampilan menari. Kontak tubuh secara dekat tidak pernah dikembangkan. Pakaian yang menunjukan ciri lokalitas dengan kain kamen penutup kaki dan 
pinggul dan bagian pinggang terlilit oleh kain panjang dengan dandanan hiasan ala penari Bali. Etika yang dikembangkan berukuran ruang dalam perbedayaan imajinatif gerakan tari dan pengisian dinamika yang berbentuk dengan isian candaan yang menggoda dengan menghindari hal-hal tabu, tetap memperhatikan kepuasan dalam prime etika agama yang jelas.

Gaya kedua adalah pertunjukan seni joged yang mengandalkan agresifitas gerakan seksual dengan memberi dan merangsang lawan penari untuk saling beradu sampai batas kekuatan kesopanan dan etika publik terkoyak. Beberapa bagian masih tetap sama pada pola tari Bali namun ketika proses keterlibatan penonton dilakukan mulailah aksi itu dijadikan ajang untuk menunjukan keprofesionalan penari dalam batas-batas yang sudah tidak jelas antara menari dengan merangsang. Seperti beberapa daerah di Bali gaya joged kedua sering diberhentikan di tengah-tengah pertunjukan. Lumrah hal itu terjadi karena masyarakat mungkin lebih memberi perhatian terhadap hal-hal yang bersifat tabu. Dengan kenyataan seperti itu kehadiran seni joged tipe kedua seperti yang diurai di atas telah memberi perbedaan secara simbolik terhadap keberadaan masyarakat sebagai wadah atau ruang di dalam seni pertunjukan seni joged itu berkembang. Artinya kesepahaman masyarakat terhadap konsep estetika seni tari ada yang memiliki kesadaran tinggi dan ada pula yang memahami setengah bentuk di samping tidak memiliki kepedulian terhadap dampak yang akan terjadi sehingga pembiaran terhadap gerakan tari yang tidak memenuhi nilai etika dianggap sebagai hal yang biasa menggoda menjadi dibenarkan di hadapan publik.

Dalam persoalan ini seperti dalam konsep dualitas dari Giddens memberikan pentujuk bahwa standarisasi di dalam suatu pemaknaan (penafsiran) terhadap kebudayaan dapat dilakukan dengan menghilangkan pemikiran dualisme yang cenderung memilah secara tegas gayagaya yang muncul di dalam masyarakat. Pemikiran dualitas yang menerima suatu keperbedaan sebagai bentuk budaya yang sama-sama patut diberi apresiasi, demikian Giddens dalam (Priyono.2002;11). Kenyataannya untuk pertunjuk seni joged tipe kedua masih saja eksis pada beberapa kelompok masyarakat walau di beberapa kelompok tertentu juga terjadi penolakan. Lama pertunjukan dari joged bumbung ini biasanya 4-5 jam, bergantung dari jumlah penari yang pentas pada hari itu. Satu orang penari bisa menari dengan durasi 30 menit lalu berganti ke penari lainnya, begitu sampai seluruh penari selesai menari.
Penikmat atau penonton dari joged bumbung ini tidak hanya masyarakat Bali.

Berdasarkan hasil wawancara dengan masyarakat Seputih Banyak dan di Desa Joharan Kecamatan Putra Rumbia Lampung Tengah banyak masyarakat lain, baik suku Lampung, jawa sunda dan lainnya sangat suka dan rela datang jauh-jauh untuk menyaksikan pertunjuka ini. Hal ini menunjukan bahwa kesenian Bali atau dalam hal ini jogged bumbung diterima dan dinikamti oleh semua masyarakat di Lampung Tengah khususnya. Kelompok joged bumbung yang sudah sangat terkenal adalah joged bumbung dari Merapi kabupaten lampung tengah. Seringkali warga Bali banjar dewa yang meminta kelompok ini untuk pentas dalam acara pernikahan. Kelompok joged ini sudah mengalami beberapa inovasi dalam gerakan dan irama. Agar dalam setiap pementasan penonton tidak merasa bosan dengan musik dan gerakan penarinya. Gerakan penari joged sekarang ini, agak sedikit erotis dengan irama musik yang sedikit koplo. Satu-satunya pertunjukan di Bali yang memberi keterlibatan penonton di dalam suatu pementasan adalah seni joged bumbung. Selain menonton, penonton juga mendapat kesempatan untuk saling beradu keahlian menari di atas panggung, mengisi panggung dengan kreativitas menari yang mampu memberikan kegairahan suasana penonton. Dalam hal ini fungsi dari penonton tidak saja untuk menghadapi penari joged namun di balik itu menjadikan dirinya sebagai pusat perhatian yang mampu mengubah suasana menjadi lebih menghibur merupakan keberhasilan yang selalu diharapkan penonton lainnya.

Hiburan yang dianggap terjadi di atas panggung bisa saja datang karena kekakuan penari dari pihak penonton yang tidak terbiasa menari namun punya keberanian menentukan harga diri dihadapan teman sejawat yang turut menonton. Hiburan juga datang dari keunggulan penari joged mengatasi persoalan penari, penonton yang kemungkinan memiliki mental yang kurang agresif dari penari, sehingga perasaan kurang percaya diri bahkan merasa terkalahkan di atas panggung sering muncul. Penonton memang tidak memiliki kekhususan karena pakaian yang dikenakan juga beragam, ada pakaian sehari-hari, ada juga pakaian adat. Secara pentas penari joged telah menyiapkan satu kain yang diikat dipinggang tanda kesertaan dalam menari yang diikatkan langsung oleh penari joged. 


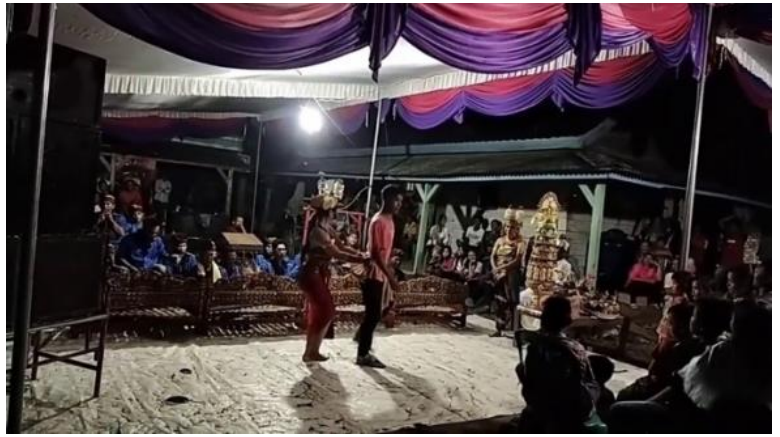

Gambar 4. Pementasan tari joged bumbung di Lampung Tengah dalam acara upacara adat (Sumber : Pan Suratningsih, 2020)

Inilah bentuk kekhasan yang diperlihatkan untuk memberi hormat kepada penonton yang terlibat menari (ngibing). Seiring perkembangan, gerakan dan irama joged sudah sedikit menyimpang dari tujuan awalnya. Sekarang ini para penari joged sudah berani bergoyang sedikit erotis yang dianggap menjurus kegerakan yang tidak baik. Para penari sudah sedikit berani menngoda para pengibing lakilaki dengan gerakan tari yang mengoda. Oleh karena itu, para pengibing laki-laki tidak segan untuk meladeni mengikuti gerakan yang dilakukan para penari joged. Sehingga sedikit banyak mengundang galak tawa dan hiteris para penonton yang menyaksikan. Harapan para penikmat joged, kelompok-kelompok tari joged mengembalikan kembali gerkan alami dari joged itu sendiri. Agar terjaganya tujuan diciptakan tarian joged pada awal diciptakan tarian ini. Oleh karena itu, adat dan budaya tetap dilestariakan tanpa adanya unsur-unsur yang dapat merusak seni itu sendiri. Mulai dari sistem kontrak telah menunjukan bukti perubahan yang terjadi pada model pemasaran kesenian tradisional. Masa lalu soal kontrak mengontrak tidak lazim ditemukan dalam sistem seni tradisi.

Kenyataannya dalam tradisi seni joged yang dilakukan adalah sistem upah (sesari). Setelah melakukan atraksi kelompok sekaa seni diberi upah berupa uang, makanan berkecukupan, akomodasi (penjemputan). Perubahan yang ditemukan dalam seni joged di Sinabun adalah sistem kontrak yang dilakukan oleh sekaa kepada penari yang dianggap potensial. Dikontrak untuk ikut bergabung dalam sekaa dimanfaatkan untuk kepentingan populeritas sekaa. Hal ini mungkin terjadi pada sekaa gabungan (bon-an) yang kemungkinan anggotanya tidak berasal dari satu desa. Bagi masyarakat adat yang ada di Bali sistem atur-aturan dalam upahan terhadap kelompok seni sudah dilakukan secara mentradisi. Setiap pengupah pertama-tama akan melakukan lobi menjelaskan alasan dan juga memastikan tempat dan waktu termasuk kesediaan sekaa untuk melakukan ayah-ayahan (pementasan). Setelah disanggupi atau mendapat persetujuan, kedatangan pengupah selanjutnya membawa tanda kepastian dengan memberi bentuk makanan khas tradisional (kawisan), berisi nasi, sate, lawar, dan lainnya yang dibuat dalam bungkusan atau kemasan tradisi. Pemberian makanan khas ini oleh pengupah merupakan bentuk tanda jadi yang memiliki etika yang sangat dalam, pertama dilihat dari pengupah adalah utusan dari kelompok masyarakat bukan perorangan, sehingga tidak lagi ada kekuatiran pembatalan. Dalam sistem upah tidak terjadi proses tawar menawar harga yang dipatok, sekaa atau seniman percaya pengupah memahami berapa jumlah upah (uang yang harus diberi). Seniman tidak pernah melakukan proses tawar menawar inilah tradisi yang sering terjadi.

Dalam budaya kapital mungkin ini adalah salah satu budaya fatalism yang dimiliki seniman tradisi. Tampaknya peribahasa lain lubuk lain ikannya mungkin patut diperhitungkan, bahwa di lain tempat budayapun berbeda kebiasaan namun berkaca dari budaya yang terjadi di masa lalu tampaknya sekaa Joged di Desa Sinabun lebih memilih transaksi yang lebih terbuka. Transaksi yang terjadi sama sekali tidak menganut sistem tertutup seperti yang dilakukan di wilayah masyarakat adat sebut saja di wilayah Gianyar atau kabupaten lainnya di Bali. Transaksi yang dipilih sudah mengaju pada sistem dagang dengan menjadikan aktor (seniman) sebagai barang. Hal itu dapat dikatakan demikian karena setelah kontrak yang dilakukan pada aktor, pemenuhan atas permintaan pengontrak hampir pasti mendapat pelayanan. Bahkan bila pelayanan atas pertunjukan yang disuguhkan itu (seni joged bumbung itu) mampu memberi kepuasan tidak tertutup kemungkinan terjadi tawaran kembali pada sang aktor untuk diberi upah tambahan.

Fakta ini menunjukan bahwa pengaruh transaksi terbuka merupakan bentuk yang berciri kapital telah mempengaruhi tindakan masyarakat di mana pemilik modal memiliki kuasa untuk mengatur upah sesuai modal tenaga dan keahlian yang diberikan. Menarik untuk melihat tindakan yang dilakukan di dalam sistem transaksi pertunjukan seni joged bumbung di Desa Sinabun. Pertama karakteristik pengupah kemungkinan besar memberi pengaruh terhadap terjadinya pembongkaran budaya sistem upah yang dianggap sebagai etika di dalam sistem transaksi masyarakat Bali mulai ditinggalkan. Kemungkinan budaya transaksi yang ada tidak terkait dengan masyarakat adat sehingga pola-pola masyarakat adat tidak terbawa dalam proses 
transaksi. Dalam panggung pertunjukan terjadi hegemoni oleh penguasa kepada kaum papa (penari). Kenyataan yang terselubung cantik di dalam dandanan yang fashionable, gerakan yang gemulai dan terkadang menantang urat, dengan alunan dinamika musikal yang sangat energik melebur seluruh ketabuan yang ada menjadi pembenaran diakui penari bukan lagi persoalan etika (struktur) seperti yang digambarkan Giddens dan teori strukturasi, namun dikatakan hal itu sebagai bentuk curahan total dalam berkesenian. Suatu bentuk pembenaran yang tidak dipahami secara sungguhsungguh dari makna seni itu sendiri. Seni itu adalah permainan demikian Aritoteles memberi difinisinya. Suatu bentuk permainan yang mengandung isi dan bentuk yang mampu menggerakan pengalaman seseorang dan bersifat adi luhung (kebenaran total).

Dalam kontekstual agama Hindu seni sangat diilhami oleh spirit siwan (benar), satyam (jujur), sundaram (suci). Beberapa contoh gerakan yang dianggap sebagai bentuk kuasa atas diri perempuan menurut pertunjukan seni joged adalah gerakan pinggul yang bergoyang menyerupai adegan seks dengan goyang mengarah berhadapan dengan penonton. Goyang pinggul dalam gerakan tari Bali sudah diperhitungkan menurut nilai etika dengan meniadakan gerakan pinggul ke arah depan penonton, di samping karena dianggap menantang birahi juga terkesan pulgar artinya tidak perlu ditutup-tutupi. Kedua gerakan kontak tubuh (mencium, memeluk, berhimpitan) secara estetik tidak pernah dikembangkan dalam pakem tari Bali. Bahkan jikapun ada gerakan pinggul maka yang dilakukan akan mengarah ke samping mengikuti perspektif dua dimensi dari arah depan penonton. Jika diperhatikan dari arah sampingpun tidak terjadi distorsi gerakan karena sudut simbolik seks pada wanita berada di bagian depan. Logika ini merupakan budaya yang memberi apresiasi terhadap ajaran norma yang sering dituliskan di dalam kitab agama Hindu yang menyebut alat vital sebagai lobang dosa tidak patut untuk didekati. Apalagi gerakan itu harus dikonsumsi publik secara pulgar tanpa adanya bentuk sensor masyarakat. Inilah yang dianggap sebagai sumber konflik di dalam budaya adiluhung. Kekuatiran atas rusaknya budaya Bali telah tergerus menjauh dari konsep ajeg Bali yang menginginkan pelestarian budaya patut direnungkan dan direkonstruksi.

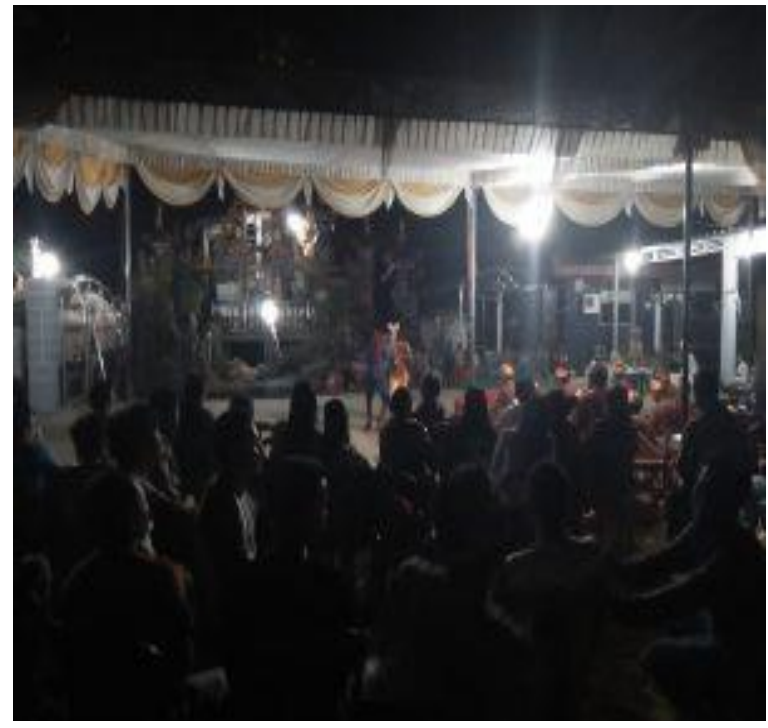

Gambar 5. Pementasan tari joged bumbung di Lampung Tengah dalam acara syukuran kelahiran seorang anak (Sumber : Pan Suratningsih, 2020)

Di Pulau Dewata siapa yang tidak mengenal joged bumbung. Joged ini merupakan joged fenomenal yang sangat dikenal oleh masyarakat Bali. Mengandung tiga unsur yaitu etika, logika dan estetika. Joged yang berasal dari Desa Kalopaksa, Seririt, Buleleng ini cukup fenomenal karena mengalami pergeseran makna tarian yang terkandung di dalamnya. Dari tarian sederhana menjadi tarian yang erotis dan sempat mendapat julukan sebagai joged porno. Sejarah terciptanya joged bumbung di Buleleng diawali dengan pementasan tarian oleh sekelompok petani di Desa Lokapaksa. Diiringi seperangkat gamelan dari bambu yang dikenal dengan sebutan ting klik mereka mengisi waktu luang di tengah keletihan mengolah lahan sawah dengan menampilkan sebuah tarian sederhana. Meski digarap dengan sederhana, nyatanya tarian tersebut mampu menghibur para petani kala itu. Beranjak dari Desa Kalopaksa kesenian ini kemudian berkembang ke beberapa desa lain di Kabupaten Buleleng dan kabupatenkabupaten lain di provinsi Bali hingga membentuk sekaa-sekaa (kelompok) joged. Pesatnya perkembangan sekaa joged bumbung di beberapa daerah di Buleleng mengakibatkan munculnya persaingan yang sangat kompetitif antar sekaa. Hal ini memaksa mereka untuk berinovasi menciptakan kreasi baru dari joged bumbung sendiri agar sekaa mereka tetap eksis dan diminati oleh masyarakat. 
Kebebasan menciptakan inovaasi baru joged bumbung ini mengakibatkan perkembangannya menjadi tidak terkontrol dan keluar dari pakemnya. Joged bumbung yang dulu memiliki makna sebagai tarian pergaulan dan merakyat, tetapi saat ini sudah dirusak oleh oknum-oknum yang tidak bertanggung jawab dan secara kasat mata terlihat sangat buruk. Munculah joged bumbung sebagai sesuatu yang fenomenal. Tidak lagi dipandang sebagai tarian yang sederhana, tetapi sudah berubah menjadi joged porno nan erotis. Kemunculan joged bumbung versi kreasi baru yang dipandang sebagai sesuatu yang erotis dan porno menimbulkan keprihatinan pemerintah provinsi dan daerah. Secara bersamasama keduanya kemudian melakukan pembinaan menyasar sekaa joged bumbung di seluruh Bali, termasuk di Buleleng. Pembinaan ini menyadarkan para seniman untuk tetap mempertahankan pakem asli kesenian joged bumbung. Pakem asli ini bagaimana tariannya tetap mengikuti etika dan sesuai norma kesopanan di masyarakat. Selain pembinaan menyangkut pakem asli, tim pembina ini juga menyarankan kepada desa pakraman untuk berpartisipasi menyarankan masyarakatnya untuk mementaskan joged bumbung sesuai pakem asli dan masih menjunjung tinggi nilai kesopanan yang berkembang di masyarakat. Bahkan tim pembina ini berencana agar desa pakraman memasukkan larangan mementaskan kesenian joged porno dalam pararem awig-awig di desa pakraman bersangkutan (Sumber:

https://kebudayaan.kemdikbud.go.id/bpnbbali/joge d-bumbung-dari-sederhana-menjadi-fenomenall).

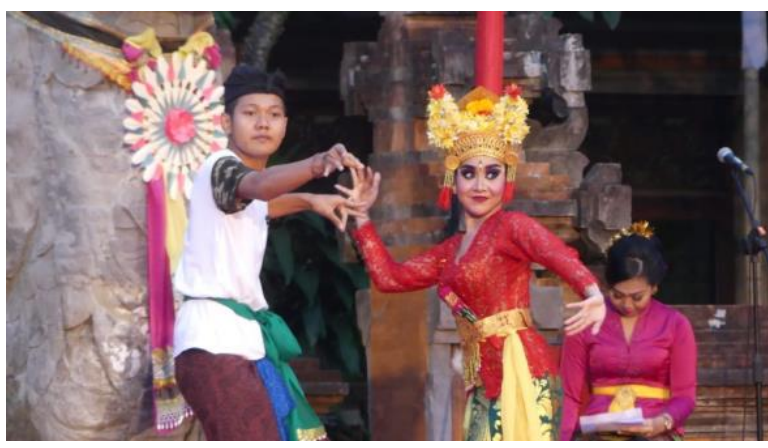

Gambar 6. (Sumber : Sanggar Suarakanti, Br. Sengguan Kawan, Desa Gianyar, Kec. Gianyar, Duta Kabupaten Gianyar Bali, 2019)

Pengaruh kesenian jathilan dan joged bumbung bagi kehidupan sosial budaya pada masyarakat etnis Jawa dan Bali di Kecamatan Seputih Banyak Kabupaten Lampung Tengah

Seni pertunjukan jathilan dan joged bumbung sebagai bagian dari kebudayaan yang di dalamnya terdapat unsur-unsur pengaruh dari budaya luar dan juga mengalami perkembangan. Budaya pop semakin tidak terbendung di era global ini dengan perkembanga teknologi semakin pesat. Dampak yang terjadi terhadap kedua bentuk kesenian ini juga mengalami perubahan dari sisi penampilan, busana, iringan, dan juga mengikuti kehidupan sosial dari budaya setempat. Budaya yang berkembang di Seputih Banyak yang sebagian besar dari keua etnik Jawa dan Bali dipengaruhi pula dengan budaya lokal yaitu Lampung. Ketiga budaya ini dapat memberi ruang terhadap perubahan kesenian dan berdampak terhadap kehidupan sosial masyarakat setempat. Faktor lingkungan menjadikan kesenian ini memiliki tempat tersendiri dan memiliki cita rasa sesuai dengan budaya yang berkembang di lingkungannya. Kedua bentuk kesenian ini memiliki selera penikmat dengan sentuhan budaya kota yang hadir di desa melalui tayangan televisi, you tube, dan lain sebagainya.

Koentjaraningrat menyebutkan bahwa, perubahan atau perkembangan kebudayaan termasuk kesenian sebaiknya tetap berorientasi pada kedua dimensi waktu, yaitu masa lampau dan masa sekarang. Pada masyarakat sekarang, perkembangan kebudayaan dihadapkan pada perkembangan ilmu pengetahuan dan teknologi (Koentjaraningrat, 1990: 108). Serupa dengan apa yang dituturkan oleh Arnold Toynbee dalam artikel Alfvin Boskoff yang berjudul "Recent Theories of Social Change" dalam Sociology and History: Theory and Research. Menurut Toynbee bahwa, perubahan sosial yang signifikan (baik pertumbuhan maupun kemunduran) disebabkan oleh tanggapan masyarakat terhadap tantangan yang mengakibatkan perubahan sosial. Perubahan sosial dipengaruhi oleh aktivitas dan kreativitas pendukungnya (Alvin Boskoff, 1964: 140-158).

Begitupula dengan perkembangan yang terjadi dalam pertunjukan kesenian jathilan dan joged bumbung pada masa lalu sampai sekarang. Perkembangan tersebut tercermin pada fungsi kesenian jathilan dan joged bumbung yang mempengaruhi pula pada perubahan bentuk pertunjukannya. Perkembangan bentuk pertunjukan kedua kesenian ini dalam konteks kehidupan masyarakat di Kecamatan Seputih Banyak tampak pada pertunjukan dari berbagai penampilannya. Di samping meliputi penari, gerak, pola lantai, musik tari, rias, busana, teknik gerak dalam menggunakan properti, tempat, dan waktu pertunjukan (Sudarsono, 1977: 41). Perubahan seni pertunjukan jathilan dan joged bumbung juga dipengaruhi oleh faktor luar seperti budaya asing yang masuk ke pedesaan, seperti melalui media televisi maupun elektronik. Perubahan internal terjadi pada perkembangan cara berpikir masyarakat pendukung 
atau pemilik kedua kesenian ini. Perkembangan seni pertunjukan jathilan dan joged bumbung tentu mengalami proses perubahan di kalangan masyarakatnya, sehingga muncul berbagai penampilan kedua kesenian ini. Perkembangan sudah barang tentu mengalami perubahan, namun sebaliknya perubahan belum tentu berkembang.

Sebagai sebuah bentuk karya seni tentunya jathilan dan joged bumbung memiliki peranan atau pengaruh terhadap masyarakat sekitarnya. Seperti yang telah disebutkan sebelumnya bahawa seni memiliki unsur hiburan sebagai suatu media pelepas penat dari banyak aktivitas. Jatihan dan jogged bumbung biasanya dipertunjukan diruang publik seperti lapangan, balai desan dan lain-lain hal ini menyebabkan banyaknya penonton dari segala kalangan yang dapat bebas menyaksiakan kedua bentuk kesenian ini. Hal ini lah yang tanpa sadar mandasari hubungan antara kedua etnis masyarakat yaitu Jawa dan Bali. Mengingat kesenian jathilan berasal dari Jawa dan joged bumbung dari Bali.

Mayoritas penduduk di Kecamatan Seputih Banyak merupakan imigran beretnis Jawa dan Bali. Berdasarkan hasil wawancara dengan masyarakat di kecamatan Seputih Banyak, mereka sadar bahwa keberadaan jathilan atau joged bumbung merupakan hal yang dinanti. Walaupun jathilan berasal dari Jawa namun ketika pertunjukan berlangsung penonton sudah melebur tidak ada lagi batasan antara etnis Jawa dan Bali begitu juga ketika pertunjukan jogged bumbung berlangsung. Masyarakat tidak memeprdulikan batasan, mereka datang untuk menyaksikan hiburan dan dalam rangka melestarikan kebudayaan dan identitas mereka. Hal ini berkaitan dengan fungsi dari kebudayaan itu sendiri yaitu sebagai identitas dan pemersatu bangsa. Masyarakat Seputih Banyak yang merupakan imigran dapat memepertahankan kesenian yang mereka bawa dari daerah asal mereka. Masyarkat etnis Bali mampu mempertahankan segala bentuk tradisinya termasuk kesenian jogged bumbung, walaupun terdapat perbedaan hal ini tidak mengurangi peran dan fungsi dari kesenian tersebut. Perbedaan sebuah bentuk kesenian juga merupakan suatu hal yang wajar, yang biasa disebut dengan akulturasi (Wawancara: Pan Suratningsih, Joharan 4 Agustus 2020).

Penonton jathilan dan jogged bumbung tidak tersekat pada etnis dari pendukung kesenian tersebut saja. Tanpa disadari dengan melihat atau menjadi penonton dalam sebuah kesenian tradisi dapat menghapus sekat dari perbedaan etnis. Hal ini menjadi pengaruh yang begitu nyata sebuah kesenian terhadap kehidupan sosial masyarakat. Dengan melihat dan menyaksikan bentuk keseniannya tanpa disadari juga dapat mempelajari nilai budaya yang terkandung didalamnya, dengan mengenal dan mempelajari nilai budaya tersebut maka masyarakat dapat saling memahami dan mengurangi dampak gesekan dari kedua etnis tersebut. Hal ini yang terjadi di kecamatan Seputih Banyak Lampung Tengah, berdasarkan hasil wawancara dengan warga selain melalui interaksi langsung masyarakat Bali mengenal masyarakat Jawa melalui keseniannya. Bagaimana kebiasaan, cara hidup, bahasa, dan lain-lain, hal ini juga yang membuat masyarakat etnis Bali menghargai etnis Jawa dengan memahami kultur yang dibawa. Begitu juga sebaliknya amsyarakat etnis Jawa kepada masyarakat etnis Bali (Wawancara: Wayan Andreas, Seputih Banyak 20 Agustus 2020).

Selain dari segi penonton, pengaruh yang sangat terlihat adalah dari rasa saling memiliki. Rasa saling memiliki ini dihasilkan karena masyarakat sudah saling mengenal satu sama lain. Tidak hanya mengenal secraa personal melainkan juga mengenal budayanya dari sebuah bentuk kesenian yaitu jathilan dan jogged bumbung. Rasa saling memiliki ini yang mewujudkan nilai bhineka tunggal ika yang dimiliki oleh bangsa Indonesia yang mana walaupun berbeda-beda namun tetap satu jua. Walaupun terdapat perbedaan etnis di kecamatan Seputih Banyak Lampung Tengah namun masyarakatnya dapat hidup rukun, hal ini tidak terlepas dari pengaruh kesenian yang berkembang pada msyarakatnya. Tidak salah jika dikatakan budaya atau kesenian yang termasuk didalamnya merupakan suatu alat untuk mempersatu bangsa.

Berdasarkan pengertian kerukunan yang telah disebutkan sebelumnya, jathilan dan jogged bumbung berhasil menciptakan rasa saling percaya, saling menghargai dan memaknai sikap kebersamaan. Jathilan dan jogged bumbung yang merupakan jenis kesenian kerakyatan yang mana tidak ada batasan penonton, atau secara pertunjukan bebas dinikmati oleh siapa saja. Hal ini yang mengakibatkan rasa saling menghormati dan menghargai kebersamaan. Menonton kesenian tersebut menjadi sebah moment yang langka dan menjadi ajang silahturahmi bagi siapapun yang menontonnya. Hal ini membuat masyarakat lebih mengharagai betapa pentingnya kebersamaan. Kerukunan masyarakat dapat terwujud dikarenakan adanya kesamaan visi secara umum antara masyarakat tersebut. Kesamaan visi pada masyarakat etnis Jawa dan Bali di kecamatan Seputih Banyak adalah untuk mempertahankan 
budaya leluhur yang mereka bawa dari tempat asalnya. Selain itu juga untuk memepertahankan identitas etnis mereka sebagai imigran.

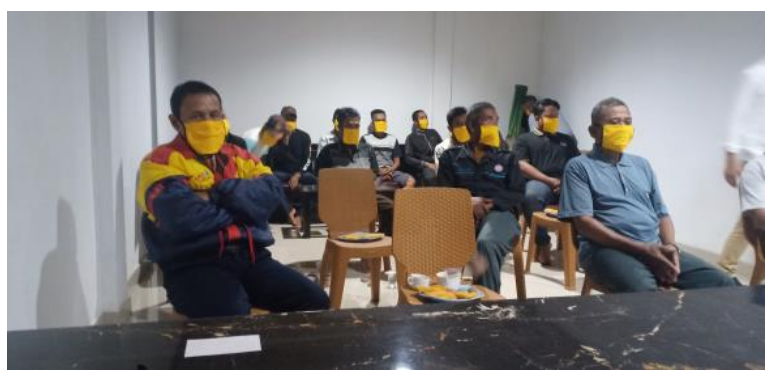

Gambar 7. Pertemuan panguyuban jathilan dan joged bumbung dalam situasi covid 19 di Kecamatan Seputih Banyak Lampung Tengah (Sumber : Nyoman Agus, 2020)

Seni jathilan dan joged bumbung merupakan sebuah seni pertunjukan yang sebagian besar ditampilkan di alam terbuka. Dengan kebebasan cara menampilkannya, seni ini memiliki gaya penampilan yang berbeda dengan seni pertunjukan yang lainnya di Lampung. Misalnya kebebasan pemain jathilan penari joged bumbung untuk menuangkan ekspresinya, seperti tingkah atau pola gerak yang dimainkan. Kekocakan dan keerotisan yang ditonjolkan menjadi andalan dalam pertunjukannya, sehingga mengundang gelak tawa dan kegairahan dari penonton. Dengan keunikannya ini, orang yang pernah menyaksikan pertunjukan jathilan dan joged bumbung akan selalu ingat dengan gaya penampilan seluru pemain jathilan dan joged bumbung di Desa Setia bakti dan Desa Joharan di Lampung tengah. Seputih Banyak dan Putra Rumbia identik dengan pertunjukan jathilan dan joged bumbung yang sudah melekat dengan masyarakat setempat. Oleh karena itu, jathilan dan joged bumbung cepat dikenal oleh masyarakat Lampung. Kesenian jathilan dan joged bumbung tumbuh dan berkembang dengan sistem pewarisan yang disampaikan melalui adat dan tradisi masingmasing dari masyarakat etnik Jawa dan Bali yang ada di Kecamatan Seputh Banyak. Seni berkembang sesuai dengan perkembangan ilmu pengetahuan, dipengaruhi lingkungan, dan juga sebagai potret karakter yang diwujudkan dalam perilaku kehidupan bermasyarakat (Mustika, 2014:105). Untuk menjaga seni pertunjukan ini tetap ada sebagai warisan, setiap desa membuat perkumpulan jathilan dan jogeg bumbung. Jathilan dan joged bumbung yang merupakan warisan yang sudah barang tentu dianggap sebagai bagian dari kebutuhan penting atau sebagai simbol persatuan dan kekerabatan. Ditampilkannya jathilan dan joged bumbung dapat dijadikan sebagai ajang berkumpulnya masyarakat dari beberapa desa di Seputuh Banyak.

\section{SIMPULAN}

Dari paparan di atas bisa ditarik beberapa kesimpulan sebagai berikut. Pertama, Kecamatan Seputih Banyak Kabupaten Lampung Tengah merupakan daerah tujuan transmigrasi dan sebagian besar masyarakatnya dari etnis Jawa dan Bali. Kehadiran kedua etnis ini membawa bahasa, seni, adat, dan budayanya ke Lampung. Tidak mengherankan nama desa yang didiami juga diberi nama daerahnya di Jawa. Seperti Desa Setia Bakti dan begitu juga dalam berinteraksi bahasa Jawa yang dominan, serta selebihnya bahasa Bali. Hubungan dari kedua etnis ini sangat erat, baik dari sisi pergaulan, pertanian, dan juga kekerabatan. Dalam kekerabatan terjalin dengan adanya perkawinan atar etnis, sehingga secara tidak langsung ada ikatan emosional dari kedua belah pihak.

Kedua, Jathilan dan joged bumbung merupakan kesenian tradisi masyarakat yang keberadaan serta eksistensinya masih terjaga. Jathilan merupakan salah satu bentuk kesenian kerakyatan dimiliki masyarakat Jawa yang hidup dan berkembang di tengah masyarakatnya. Begitu pula jogged bumbung merupakan kesenian rakyat dimiliki oleh masyarakat beretnis Bali. Kesamaan dari kedua bentuk kesenian di Kecamata Seputih Banyak adalah karena keduanya merupakan budaya yang dibawa oleh imigran dan mampu bertahan bahkan menyesuaikan diri di perantauan hingga saat ini. Masyarakat Seputih Banyak menjadikan kesenian sebagai alat pemersatu dan menghilangkan sekat antar etnis. Hal ini terlihat dari minat masyarakat terhadap kesenian tersebut, penonton serta pelaku seninya yang tidak lagi terbatas kepada etnis tertentu saja, melainkan sudah melebur menjadi satu.

Ketiga, jathilan dan jogged bumbung menjadi bentuk nyata kerukunan yang terwujud dari seni dan budaya masyarakat. Dari sisi seni pertunjukan kedua kesenian ini dapat menghibur, seperti menyegarkan pikiran, menghilangkan stres, dan menikmati indahnya gerak penari joged bumbung, dan mampu menghadirkan atau mengumpulkan masyarakat dari berbagai desa dengan latar belakang etnis yang berbeda. Untuk tataran sosial, masyarakat secara tidak langsung terhubung antara satu dengan yang lainnya dalam satu pertunjukan yang sama. Dengan adanya kontak budaya dari sisi seni, bahasa, adat, karakter, dan juga pertukaran informasi dapat mewujudkan dan menambah pengetahuan dari kedua masyarakat tersebut. Dari ketiga penjelasan tersebut bahwa, kesenian atau dalam hal ini seni tari 
dapat menjadi landasan atau sebuah media pemersatu dan menjadi contoh kepada daerah lain yang memiliki masyarakat yang heterogen.

Keempat, jathilan dan jogeg bumbung sebagai sarana sosialisasi, sebagai media untuk berinteraksi antara pemerintah dengan masyarakat, dan juga interaksi antar warga. Sebagai contoh, untuk sosialisasi kenakalan remaja, program kerukunan, dan untuk menyampaikan pesan-pesan bermuatan politik, biasanya para politikus ikut hadir membagikan bingkisan kepada masyarakat melalui kesenian. Jathilan dan joged bumbung juga sebagai solidaritas sosial bertujuan membangun rasa kebersamaan dalam kehidupan bermasyarakat, seperti mendukung dan melaksanakan program pemerintah dalam pembangunan desa secara bersama-sama. Dengan adanya solidaritas ini secara tidak langsung terbangun sistem sosial, seperti aktivitas manusia yang berinteraksi, berhubungan, serta bergaul satu dengan yang lainnya dari waktu ke waktu.

Kelima, dengan adanya wabah corona atau covid 19 kelompok kesenian jathilan dan joged bumbung mengalami kemandegan atau pemberhentian sementara selama wabah berlangsung. Hampir selama satu tahun lebih kedua paguyuban kesenian ini tidak lagi dapat tanggapan dari masyarakat. Karena tidak mendapatkan ijijn pentas dan dilarang dari pemerintah untuk mengumpulkan massa. Untuk itu semua peserta dan anggota penguyuban kesenian ini hanya bisa latihan secara mandiri di rumah dan ditempat paguyuban.

\section{DAFTAR RUJUKAN}

Ardianto, D. T., \& Riyanto, B. (2020). Film Tari; Sebuah Hibridasi Seni Tari, Teknologi Sinema, dan Media Baru. Mudra Jurnal Seni Budaya, 35(1), 112-116. https://doi.org/10.31091/mudra.v35i1.856

Alfian, ed. (1985). Persepsi Manusia Tentang Kebudayaan. Jakarta: Gramedia.

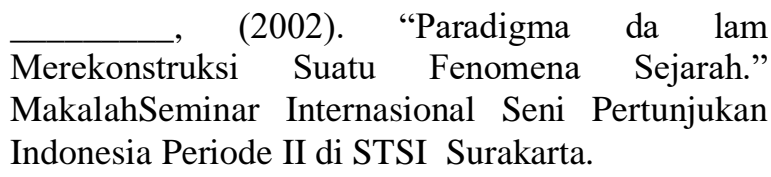

Barker Chris, 2000, “ Cultural Studies, Teoeri dan Praktek", Penerbit PT. Bintang Pustaka ; Yogjakarta.

Boskoff, Alvin. (1964) "Recent Theories of Social Changes" dalam Werner J. Cahman dan Alvin
Boskoff, ed., Sociology and History: Theory and Research. London: The Free Press Glencoe.

Handayani, D., \& Sunarso, S. (2020). Eksistensi Budaya Pappaseng Sebagai Sarana Pendidikan Moral. Mudra Jurnal Seni Budaya, 35(2), 232-241. https://doi.org/10.31091/mudra.v35i2.974

Djelantik, 1992. "Pengantar Filsafat Keindahan dan kesenian", Penerbit STSI Denpasar; Denpasar. Ibrahim, Edy Subandi Editor,1997, "Life Style Ecstasy", Penerbit Jalasutra IKAPI; Bandung.

Hauser, Arnold. (1982). The Sociology of Art. Terj. Kenneth J. Northcott. Chicago: The University of Chicago Press.

Hawkins, Alma M. (2003). Bergerak Menurut Kata Hati: Metoda Baru dalam Menciptakan Tari. Terj. I Wayan Dibia. Jakarta: Masyarakat Seni Pertunjukan Indonesia.

Karmini, N. N. (2019). Nilai-Nilai Budaya Dalam Tam Tam. Mudra Jurnal Seni Budaya, 34(1), 8-18. https://doi.org/10.31091/mudra.v34i1.630

Koentjaraningrat. (1990). Sejarah Teori Antropologi II. Jakarta: Universitas Indonesia UI Press.

Lubis Akhyar Yusuf, 2014, "Filsafat Ilmu Klasik Hingga Kontemporer, Penerbit PT. Raja Grafindo Persada; Jakarta.

Marinis, Marco De. (1993).The Semiotics of Performance. Terj. Aine O'Healy. Blongmingtondan Indianapolis: Indiana University Press.

Mulyatiningsih, Endang. (2013). Metode Penelitian Terapan Bidang Pendidikan. Bandung: Alfabeta

Mustika, I Wayan. (2010). Mengenal Tari Bedayo Tulang Bawang Sebagai Sebuah Seni Pertunjukan. Yogayakarta: UPN.

(2011). Sekilas Budaya Lampung dan Seni Tari Pertunjukan Tradisionalnya. Lampung: Buana Cipta.

Lampung: AURA. “ (2013) Tari Muli Siger. ,“ (2013) Teknik Dasar Gerak tari Lampung. Lampung: AURA. 
,“ (2014). Sakura Nyakak Buah di

Kabupaten Lampung Barat. Mudra Jurnal Seni Budaya. Volume 29. No. 1 Februari.

Narawati, Tati. (2003). Wajah Tari Sunda Dari Masa Ke Masa. Bandung: P4ST UPI

\begin{tabular}{|c|c|c|}
\hline & $(2013)$ & Proseding \\
\hline "Etnokoreologi: & Pengkajian Tari & Etnis da \\
\hline Kegunaannya & Dalam & Pendidika \\
\hline $\begin{array}{l}\text { Seni.http://ejour } \\
\text { view/4005 }\end{array}$ & unp.ac.id/inde & isla/article \\
\hline
\end{tabular}

Plekanov, G.V. (1957). Art and Social Life. Moscow: Foreign Languages Publishing House

Priyono, Herry, 2002. "Anthony Giddens sebuah Pengantar", Penerbit Kepustakaan popular Gramedia; Jakarta.

Santoso Listiyono, Dkk,2014, "Seri Pemikiran Tokoh Epistimologi Kiri",Penerbit AR-RUZZ Media; Yogjakarta. Sutrisno SJ, FX. Mudji, dkk., 1993. "Estetika Filsafat Keindahan”, Penerbit Kanisius IKAPI; Yogyakarta.

Schechner, Richard. (2002). Performance Studies. New York: St Edmundsbury Press.

R.M. Soedarsono. (2002). Seni Pertunjukan Indonesia di Era Globalisasi (Yogyakarta: Gadjah Mada University Press.

Sudarsono [R.M. Soedarsono]. (1977). Tari-Tarian Indonesia I (Jakarta: Proyek Pengembangan Media Kebudayaaan, Direktorat Jendral Kebudayaan, Departemen Pendidikan dan Kebudayaan.

Sugiyono. (2014). Metode Penelitian Kombinasi. Bandung: Alfabeta

Suyono dan Suyatno. (2014). Revitalisasi Kearifan Lokal sebagai Upaya Penguatan Identitas Keindonesian. Tersedia: http://badanbahasa.kemdikbud.go.id/lamanbahasa/ content/revitalisasi-kearifan-lokalsebagai-upayapenguatan-identitas-keindonesiaan, diakses 25 Januari 2019. 